\title{
Diagnostic Cytochrome $b$ gene profiles for the identification of paca (Cuniculus paca) bushmeat: implications for the monitoring of illegal hunting and wildlife trade
}

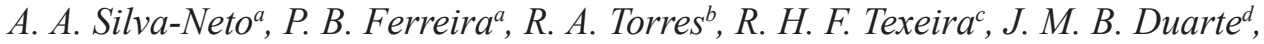 \\ A. C. Barbosa ${ }^{e}$, R. C. Vargas and J. E. Garcia $^{a *}$ \\ ${ }^{a}$ Centro Acadêmico de Vitória, Universidade Federal de Pernambuco - UFPE, Rua Alto do Reservatório, s/n, \\ Bela Vista, CEP 55608-680, Vitória de Santo Antão, PE, Brazil \\ 'Laboratório de Genômica Evolutiva e Ambiental, Departamento de Zoologia, Centro de Ciências Biológicas, \\ Universidade Federal de Pernambuco - UFPE, Av. Prof. Nelson Chaves, s/n, Cidade Universitária, \\ CEP 50670-901, Recife, PE, Brazil \\ 'Parque Zoológico Municipal Quinzinho de Barros, Rua Teodoro Kaisel, 883, \\ Vila Hortência, CEP 18020-268, Sorocaba, SP, Brazil \\ dNúcleo de Pesquisa e Conservação de Cervídeos, Faculdade de Ciências Agrárias e Veterinárias, \\ Universidade Estadual Paulista - UNESP, Via de Acesso Prof. Paulo Donato Castellane, s/n, \\ CEP 14884-900, Jaboticabal, SP, Brazil \\ 'Instituto Federal Minas Gerais - IFMG, Fazenda Varginha, Km 5, s/n, Rodovia Bambuí/Medeiros, \\ CP 05, CEP 38900-000, Zona Rural Bambuí, MG, Brazil \\ *e-mail: jegarcia30@gmail.com
}

Received: June 2, 2014 - Accepted: October 22, 2014 - Distributed: February 29, 2016

(With 2 figures)

\begin{abstract}
Paca (Cuniculus paca Linnaeus, 1766) is the second largest rodent found in Brazil. The quality of the meat and a long tradition of hunting have contributed to the decline of the natural populations of this species. Hunting of paca is strictly prohibited in Brazil, but in spite of this restriction, no forensic tools are available for the identification of the meat. We describe an efficient method, based on single nucleotide polymorphisms of the cytochrome $b$ gene, that can be used to differentiate biological material derived from paca from those of domestic species commonly used as sources of meat. The identification of the presence of C. paca in the samples was $100 \%$ reliable.
\end{abstract}

Keywords: forensic science, Cytochrome $b$, wild rodent, molecular markers.

\section{Perfis diagnósticos do gene Citocromo b para a identificação molecular de paca (Cuniculus paca): implicações para a deteç̧ão e monitoramento de caça e comércio ilegal}

\section{Resumo}

Paca (Cuniculus paca Linnaeus, 1766) é o segundo maior roedor brasileiro. A qualidade da carne e a forte tradição da caça de subsistência são fatores que contribuem significativamente para o declínio das populações. Apesar da proibição a caça no Brasil, no momento ainda não há ferramentas disponíveis para identificar a carne e seus produtos como prova forense. Neste trabalho propomos um método eficaz de identificação, baseado em polimorfismos de único nucleotídeo no gene Citocromo b, objetivando diferenciar material biológico de paca das espécies domésticas comumente utilizadas como alimento no Brasil. A identificação das amostras de paca foram possíveis em 100\% das amostras analisadas.

Palavras-chave: ciência forense, Citocromo b, roedor selvagem, marcador molecular.

\section{Introduction}

Poaching and the consumption of wild game (bushmeat) are important factors in the decline and extinction of many animal species from natural environments at both regional and international levels (Eaton et al., 2010).
Historically, the hunting of game in tropical regions has been a subsistence activity with some local commerce. In addition to subsistence, certain wild species have been used traditionally as pets or for religious rituals, and there 
is often a demand for exotic meats in urban populations. Over-exploitation of wild populations may lead to local extinctions and ultimately, the extinction of the species. In the semi-arid Brazilian Northeast, for example, there is a long tradition of subsistence hunting, which is perpetuated by a culture of bushmeat consumption. This activity appears to contribute not only to local extinctions, but also to environmental degradation (Alves et al., 2009).

Despite the existence of national legislation and international treaties governing the wildlife trade, such as the Convention on the International Trade of Endangered Species (CITES), the lack of reliable methods for the identification of products such as skins and processed meat (which have no morphological cues for the identification of the species) hampers the implementation of laws. The reliable detection of species for the monitoring and control of the illegal trade in wildlife products can only be guaranteed by the development of accurate and cost-effective DNA diagnostic tools (Eaton et al., 2010).

Nucleotide sequences, in particular standardized genomic regions, such as those of the mitochondrial cytochrome $c$ oxidase subunit I (COI) and cytochrome $b$ (Cyt $b$ ) genes, have been proposed as important tools for the identification of species. This approach has proven useful for the identification of species in research ranging from epidemiological studies to the screening of both the legal and illegal trade in wildlife and wildlife products (Moore et al., 2003; Sobrino et al., 2005; Eaton et al., 2010; Schlegel et al., 2012). Single nucleotide polymorphisms (SNPs) have become one of the most robust markers for the resolution of complex legal questions due to the fact that these mutations are abundant and widespread in the genomes of most species (Morin et al., 2004). These molecular markers can be detected by using the polymerase chain reaction (PCR) followed by digestion with specific restriction enzymes (PCR/RFLP), and have been one of the most important recent innovations in the fields of ecology and conservation (Morin et al., 2004). These markers are not only reliable and sensitive, but also relatively low cost (Yan et al., 2005). Malisa et al. (2006) described a PCR/RFLP-based protocol for a fragment of the mitochondrial D-loop gene which was effective for the identification of 10 wild African species affected by illegal hunting.

The paca (Cuniculus paca; Agoutidae) is the second largest Neotropical rodent. It occurs in all Central and South America, from Argentina, reaching to North America in Mexico, occupying a variety of habitats, such as grasslands, forests, and agricultural areas (Wilson and Reeder, 2005). At the present time, the illegal hunting of C. paca for its meat is probably second only to that of the nine-banded armadillo, Dasypus novemcinctus (Freitas and Silva, 2005), and this hunting pressure may increasingly threaten the integrity and long-term survival prospects of many wild populations.

In a recent study, Ferreira et al. (2011) successfully used RFLP and SNP markers to diagnose samples in a forensic study of endangered manatees, and supported the use of both techniques in the enforcement of legislation against hunting and the illegal wildlife trade. In the present paper, a simple, fast, and cost-effective molecular tool was developed for the identification of nucleotide polymorphisms in the Cyt $b$ gene capable of differentiating biological samples derived from the paca from those of domestic species commonly used for the production of meat in the Neotropics (cow, goat, sheep, and pig).

\section{Material and Methods}

Eight polymorphic partial cytochrome $b$ sequences (395 bps, on average) from C. paca, sequences from three other Neotropical rodents (Akodon paranaensis, Euryzygomatomys spinosus and Hydrochoerus hydrochaeris), and the complete sequences of four domestic species (Bos taurus, Capra hircus, Sus scrofa, and Ovis aries) were retrieved from GenBank in FASTA format. Nucleotide similarities were identified using Sequencher 4.8 (Gene Codes). Sequence alignments were run in Clustal W (BioEdit 6.0.7), with minor adjustments being conducted manually. Nucleotide polymorphisms and restriction enzyme sites were identified using the Cleaver software (Jarman, 2006). These complete sequences from domestic animals were trimmed to align them with the 395-bp fragment from C. paca and 141 SNPs were identified in the homologous block of the Cyt $b$. Of these SNPs, 37 were diagnostic of C. paca, and two were associated with the restriction site for the enzymes BsiEI (CGRYCG) and MspA1I (CMGCKG). Degenerate primers capable of amplifying a homologous fragment in all species were designed using Gene Runner 3.0.5 (Hastings Software Inc.).

The DNA was isolated from 21 samples of paca muscle tissue using Qiamp Blood and Tissue Kit (Qiagem Inc.) following the manufacturer's protocol. The samples were obtained in Brazil from the Wild Animal Facility of the UNESP Animal Science Department in Jaboticabal, São Paulo $(n=10)$ and the Bambuí Campus of the Minas Gerais Federal Institute in Minas Gerais $(n=11)$. Samples of domestic mammals were obtained from the public market in Olinda and the University Federal Rural of Pernambuco, both located in the Brazilian state of Pernambuco. The DNA in the samples was quantified in $1 \%$ agarose gel stained with GelRed (Biotium, Hayward, CA, USA). The PCR amplification was conducted in a final reaction volume of $20 \mu \mathrm{l}$ using the pair of degenerate primers described here - Forw 5'CTYCCHRCYCCMTCHAAYAT3' and Rev 5'GDAGRABKAYKCCRATRTTTC3'. The PCR reaction contained $1 \mathrm{X}$ buffer, $2.5 \mathrm{mM} \mathrm{MgCl}, 2 \mathrm{mM}$ of each $\mathrm{dNTP}, 20 \mathrm{pM} / \mu \mathrm{l}$ of each primer, $1 \mathrm{U}$ Taq DNA Polymerase (LGC, Brazil), and $50 \mathrm{ng}$ of DNA, and was based on an initial denaturation step of $2 \mathrm{~min}$ at $95^{\circ} \mathrm{C}$, followed by 40 cycles of $2 \mathrm{~min}$ at $92^{\circ} \mathrm{C}, 2 \mathrm{~min}$ at $61^{\circ} \mathrm{C}$, and $1.5 \mathrm{~min}$ at $72^{\circ} \mathrm{C}$, with a final extension of $10 \mathrm{~min}$ at $72^{\circ} \mathrm{C}$ for the conclusion of the profile. The amplicons were digested with $2 \mathrm{U}$ of BsiEI, according to the manufacturer's protocol. The products of the digestion procedure were analyzed by electrophoresis in $2 \%$ agarose gel stained with GelRed. 


\section{Results}

The set of primers designed for the present study performed satisfactorily in the PCR, generating a standard fragment of approximately $298 \mathrm{bps}$ for all of the species analyzed (Figure 1). The comparison of this fragment with the complete sequence of 1200 bps (DQ186290: Bos taurus) revealed a BsiEI digestion site in the Cyt $b$ gene of C. paca, which generates two fragments (237 and $61 \mathrm{bps}$ ). This site is characterized by a substitution of the adenine present in the sequences of the domestic animals with cytosine in the paca (Figure 2). The sequences of pacas analyzed were monomorphic in the restriction site. Following digestion by BsiEI, a 237 bp band could be observed in the $2 \%$ agarose gel in all samples from C. paca (Figure 1). The shorter band was not visible in the gel and, for some reason, a portion of the undigested fragment of $298 \mathrm{bp}$ was observed in all $C$. paca samples, although it did not interfere with the differentiation of this species from the domestic animals.

\section{Discussion}

Forensic DNA procedures have gained increasing ground in the scientific community given their usefulness for the monitoring and diagnosis of animal species, and their practical applications for the enforcement of the legislation controlling the trade in wildlife (Eaton et al., 2010). In particular, a reliable protocol for the diagnosis of the genetic signature of a target species is an essential step in the development of a forensic DNA tool. The results of the present study indicate that two transversion-type

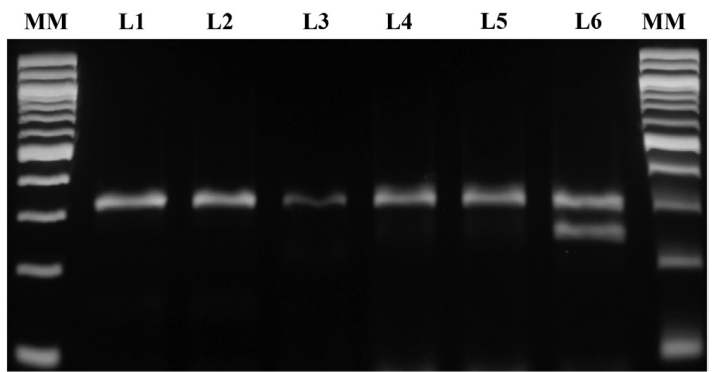

Figure 1. Gel electrophoresis of the cytochrome $b$ PCR/RFLP profiles for four domestic species (L1-L4) and $C$. paca (L5). MM = 100 bp DNA Ladder (BioLabs), $\mathrm{L} 1=$ Bos indicus, L2 = Capra hircus, L3 = Sus scrofa, L4 $=$ Ovis aries, based on a $\sim 298$ bp cytochrome $b$ fragment treated with BsiEI; L5 $=$ sample of $C$. paca not digested with BsiEI, and L6 $=C$. paca partially digested with the BsiEI enzyme $(237+61$ bps $)$. substitutions can be diagnosed using both SNP and PCR-RFLP markers. While transversions are the least common type of point mutation responsible for the diversity of the mitochondrial genome, transversion-based SNPs appear to be reliable markers for the differentiation of a number of domestic animals, as well as some endangered mammals such as manatees (Ferreira et al., 2011). Although complete digestion was not observed in any paca sample, they all presented bands consistent with the expected restriction profile, confirming the effectiveness of this method, and supporting its use for the forensic monitoring of the illegal exploitation of this wild species.

The technology for the genotyping of SNPs has advanced rapidly in recent years, and this approach has become the most suitable for forensic purposes given its accuracy and reproducibility (Sobrino et al., 2005; Ferreira et al., 2011). The legally-valid discrimination of meat products demands an extremely low probability of misassignment, which may depend on the analysis of a large number of samples in order to guarantee that all possible variants have been identified (Moore et al., 2003). In addition, a number of studies have demonstrated that it is possible to differentiate species even where DNA has been mixed, and also that the PCR/RFLP technique can be applied to processed meat products, even when they have been cooked (Wolf et al., 1999).

The findings of the present study nevertheless emphasized the need for caution with regard to the possible presence of undigested fragments following the PCR (see Figure 1). Zehner et al. (1998) discussed the possible need to inhibit the cleavage of substances originating from exogenous DNA, which may be transferred together with the template DNA to the PCR. As the PCR products of all the 21 samples were not completely digested even after numerous repetitions of the PCR reaction, the possibility of such contamination is greatly reduced.

One of the main steps in the development of an accurate DNA forensic protocol is the choice of an appropriate sector of the genome for analysis, one that will guarantee reliable diagnosis. In the mitochondrial genome of mammals, $\mathrm{COI}$ and Cyt $b$ are the slowest-evolving genes in terms of non-synonymous mutations (Pesole et al., 1999), which makes them highly appropriate for the diagnosis of the unique genetic signatures of species. The data obtained in the present study reinforce previous findings on the applicability of the Cyt $b$ gene for the diagnosis of Cuniculus paca. The results also reinforce the use of Cyt $b$ profiles as a molecular tool for the identification of a number of different vertebrate species impacted by the illegal wildlife trade, such as sharks (Kumar et al., 2007),

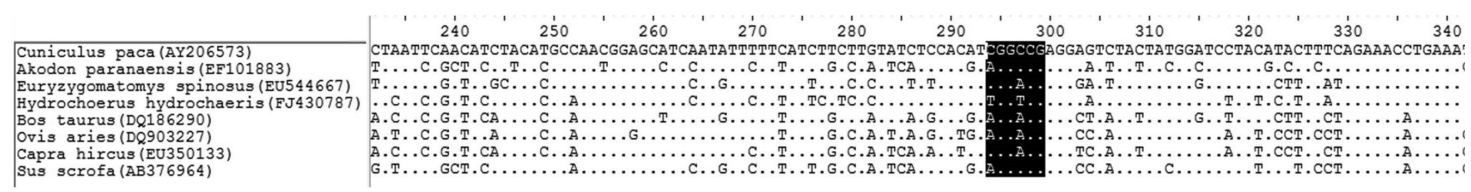

Figure 2. Alignment of the nucleotide sequences showing the BsiEI digestion site (CGRYCG). In brackets the GenBank accession numbers from nucleotide sequences. 
seals (Malik et al., 1997), marine turtles (Moore et al., 2003), snakes (Yau et al., 2002), felids (Wan and Fang, 2003), and manatees (Ferreira et al., 2011).

The protocol described in the present study is a simple and reliable procedure for the identification of biological material from C. paca and its differentiation from samples of four domestic animals commonly used as a source of meat in the Neotropical region (B. taurus, S. scrofa, $O$. aries, and $C$. hircus). This simple PCR/RFLP protocol for the identification of Cyt $b$ gene sequences appears to represent a potentially useful and important tool for the protection of $C$. paca populations from hunting for the illegal bushmeat trade. This technique may be useful not only for the forensic identification of bushmeat samples, but also ecological studies in which the occurrence of the species and the feeding behavior of predators may be verified through the analysis of stomach contents.

\section{Acknowledgements}

We would like to thank our partners who provided the samples analyzed in this study who contributed directly or indirectly to its success. This study was funded by Fundação de Amparo à Ciência e Tecnologia do Estado de Pernambuco: Grants, P.B.F and A.A.Silva-Neto scholarships (Processes APQ-0402-2.01/-8, IBPG-1483-2.01/08, BIC-0254-2.01/09), and Conselho Nacional de Desenvolvimento Científico e Tecnológico (CNPq) through fellowships to R.A.T. and J.M.B.D.

\section{References}

ALVES, R.R.N., MENDONÇA, L.E.T., CONFESSOR, M.V.A., VIEIRA, W.L.S. and LOPEZ, L.C.S., 2009. Hunting strategies used in the semi-arid region of northeastern Brazil. Journal of Ethnobiology and Ethnomedicine, vol. 5, no. 1, pp. 12. http:// dx.doi.org/10.1186/1746-4269-5-12. PMid:19386121.

EATON, M.J., MEYERS, G.L., KOLOKOTRONIS, S.O., LESLIE, M.S., MARTIN, A.P. and AMATO, G., 2010. Barcoding bushmeat: molecular identification of Central African and South American harvested vertebrates. Conservation Genetics, vol. 11, no. 4, pp. 1389-1404. http://dx.doi.org/10.1007/s10592-009-9967-0.

FERREIRA, P.B., TORRES, R.A. and GARCIA, J.E., 2011. Single nucleotide polymorphisms from cytochrome $b$ gene as a useful protocol in forensic genetics against the illegal hunting of manatees: Trichechus manatus, Trichechus inunguis, Trichechus senegalensis, and Dugong dugon (Eutheria: Sirenia). Zoologia, vol. 28 , no. 1 , pp. 133-138. http://dx.doi.org/10.1590/S198446702011000100019

FREITAS, M.A. and SILVA, T.F.S., 2005. Guia ilustrado mamíferos na Bahia: espécies continentais. Pelotas: Editora USEB.

JARMAN, S.N., 2006. Cleaver: software for identifying taxon specific restriction endonuclease recognition sites. Bioinformatics, vol. 22, no. 17, pp. 2160-2161. http://dx.doi.org/10.1093/ bioinformatics/btl330. PMid:16787976.

KUMAR, R., SINGH, P.J., NAGPURE, N.S., KUSHWAHA, B., SRIVASTAVA, S.K. and LAKRA, W.S., 2007. A non-invasive technique for rapid extraction of DNA from fish scales. Indian Journal of Experimental Biology, vol. 45, no. 11, pp. 992-997. PMid: 18072545.
MALIK, S., WILSON, P.J., SMITH, R.J., LAVIGNE, D.M. and WHITE, B.N., 1997. Pinniped penises in trade: a moleculargenetic investigation. Conservation Biology, vol. 11, no. 6, pp. 1365-1374. http://dx.doi.org/10.1046/j.1523-1739.1997.96125.x.

MALISA, A.L., GWAKISA, P., BALTHAZARKY, S., WASSER, S.K. and MUTAYOBA, B.M., 2006. The potential of mitochondrial DNA markers and polymerase chain reaction-restriction fragment length polymorphism for domestic and wild species identification. African Journal of Biotechnology, vol. 5, no. 18, pp. 1588-1593.

MOORE, M.K., BEMISS, J.A., RICE, S.M., QUATTRO, J.M. and WOODLEY, C.M., 2003. Use of restriction fragment lenght polymorphisms to identify sea turtle eggs and cooked meats to species. Conservation Genetics, vol. 4, no. 1, pp. 95-103. http:// dx.doi.org/10.1023/A:1021881319271.

MORIN, P.A., LUIKART, G., WAYNE, R.K., and the SNP Workshop Group, 2004. SNP in ecology, evolution and conservation. Trends in Ecology \& Evolution, vol. 19, no. 4, pp. 208-216. http://dx.doi. org/10.1016/j.tree.2004.01.009

PESOLE, G., GISSI, C., DE CHIRICO, A. and SACCONE, C., 1999. Nucleotide substitution rate of mammalian mitochondrial genomes. Journal of Molecular Evolution, vol. 48, no. 4, pp. 427-434. http://dx.doi.org/10.1007/PL00006487. PMid:10079281.

SCHLEGEL, M., ALI, H.S., STIEGER, N., GROSCHUP, M.H., WOLF, R. and ULRICH, R.G., 2012. Molecular identification of small mammal species using novel cytochrome $b$ gene-derived degenerated primers. Biochemical Genetics, vol. 50, no. 5-6, pp. 440-447. http://dx.doi.org/10.1007/s10528-011-9487-8. PMid:22193288.

SOBRINO, B., BRIÓN, M. and CARRACEDO, A., 2005. SNPs in forensic genetics: a review on SNP typing methodologies. Forensic Science International, vol. 154, no. 2-3, pp. 181-194. http://dx.doi.org/10.1016/j.forsciint.2004.10.020. PMid:16182964.

WAN, Q.H. and FANG, S.G., 2003. Application of speciesspecific polymerase chain reaction in the forensic identification of tiger species. Forensic Science International, vol. 131, no. 1, pp. 75-78. http://dx.doi.org/10.1016/S0379-0738(02)00398-5. PMid:12505474.

WILSON, D.E. and REEDER, D.A.M., 2005. Mammals species of the world: a taxonomic and geographic reference. Baltimore: The Johns Hopkins University Press. 2142 p.

WOLF, C., RENTSCH, J. and HÜBNER, P., 1999. PCR-RFLP analysis of mitochondrial DNA: a reliable method for species identification. Journal of Agricultural and Food Chemistry, vol. 47, no. 4, pp. 1350-1355. http://dx.doi.org/10.1021/jf9808426. PMid:10563979.

YAN, P., WU, X.B., SHI, Y., GU, C.M., WANG, R.P. and WANG, C.L., 2005. Identification of Chinese alligators (Alligator sinensis) meat by diagnostic PCR of the mitochondrial cytochrome $b$ gene. Biological Conservation, vol. 121, no. 1, pp. 45-51. http://dx.doi. org/10.1016/j.biocon.2004.04.008.

YAU, F.C.F., WONG, K.L., SHAW, P.C., BUT, P.P.H. and WANG, J., 2002. Authentication of snakes used in Chinese medicine by sequence characterized amplified region (SCAR). Biodiversity and Conservation, vol. 11, no. 9, pp. 1653-1662. http://dx.doi. org/10.1023/A:1016836017903.

ZEHNER, R., ZIMMERMANN, S. and MEBS, D., 1998. RFLP and sequence analysis of the cytochrome $b$ gene of selected animals and man: methodology and forensic application. International Journal of Legal Medicine, vol. 111, no. 6, pp. 323-327. http:// dx.doi.org/10.1007/s004140050180. PMid:9826093. 